\title{
Pengaruh Ukuran Perusahaan dan Profitabilitas pada Ketepatwaktuan Penyampaian Laporan Keuangan dengan GCG Sebagai Variabel Pemoderasi
}

\author{
Gusti Ayu Putu Yasinta Darmawan ${ }^{1}$ \\ I Made Pande Dwiana Putra ${ }^{2}$ \\ ${ }^{1}$ Fakultas Ekonomi danBisnis Universitas Udayana (Unud), Bali, Indonesia \\ email: yasinta.darmawan@gmail.com/telp: +6287 862384124 \\ ${ }^{2}$ Fakultas Ekonomi dan Bisnis Universitas Udayana (Unud), Bali, Indonesia
}

\begin{abstract}
ABSTRAK
Penelitian ini bertujuan untuk membuktikan secara empiris pengaruhukuran perusahaan dan profitabilitas pada ketepatwaktuan penyampaian laporan keuangan dengan good corporate governance sebagai variabel pemoderasi. Penelitian ini dilakukan pada perusahaan go publik non keuangan dan keuangan yang terdaftar dalam penilaian Corporate Governance Perception Index (CGPI) tahun 2011-2015. Metode penentuan sampel yang digunakan adalah menggunakan purposive sampling. Jumlah perusahaan yang memenuhi kriteria adalah 9 perusahaan dengan jumlah 43 amatan. Pengumpulan data dilakukan dengan metode observasi non partisipan.Dengan menggunakanuji regresi berganda dan moderated regression analysis (MRA) didapatkan hasil bahwa ukuran perusahaantidak berpengaruh pada ketepatwaktuan penyampaian laporan keuangan tetapi profitabilitas berpengaruh terhadap ketepatwaktuan penyampaian laporan keuangan. Penelitian ini juga menemukan bahwa good corporate governancetidak mampu memoderasi pengaruh ukuran perusahaanterhadap ketepatwaktuan penyampaian laporan keuangan tetapi mampu memoderasi dengan memperlemah pengaruh profitabilitas terhadap ketepatwaktuan penyampaian laporan keuangan

Kata kunci: Ketepatwaktuan penyampaian laporan keuangan, ukuran perusahaan, profitabilitas.
\end{abstract}

\begin{abstract}
This study aims to prove empirically the influence of company size and profitability on timely delivery of financial statements with good corporate governance as a moderator variable. This study was conducted on non-financial public and go public companies listed in the 2011-2015 corporate governance perception index (CGPI) assessment. The method of determining the sample used is to use purposive sampling. The number of companies that meet the criteria is 9 companies with a total number of 43 observations. Data collection was done by non participant observation method.. The study also found that good corporate governance is not able to moderate the influence of firm size on the timeliness of financial statement submission but able to moderate by weakening the influence of profitability on timely delivery of financial statements

Keywords: Timeliness of financial report submission, company size, profitability,
\end{abstract}

\section{PENDAHULUAN}

Laporan keuangan adalah catatan informasi keuangan suatu perusahaan pada suatu periode akuntansi yang dapat digunakan untuk menggambarkan kinerja perusahaan tersebut. Sedangkan pelaporan keuangan merupakan proses 
Gusti Ayu Putu Yasinta Darmawan dan I Made Pande Dwiana Putra. Pengaruh...

penyampaian informasi keuangan perusahaan untuk mencapai tujuan pelaporan keuangan guna mendukung pencapaian tujuan ekonomi suatu perusahaan.

Penyampaian laporan keuangan memiliki tujuan untuk memberikan informasi mengenai posisi keuangan dan kinerja serta arus kas perusahaan yang berguna bagi sebagian besar pengguna laporan keuangan dalam rangka membuat suatu keputusan ekonomi dan bisnis, sekaligus menunjukkan pertanggungjawaban manajemen atas sumber daya perusahaan yang dikelolanya. Ketepatan penyampaian laporan keuangan akan mempengaruhi para pengguna laporan keuangan dalam proses pengambilan keputusan karena semakin cepat waktu penyampaiannya, maka semakin cepat keputusan dapat diambil. Ketepatwaktuan penyampaian laporan keuangan akan memberikan pengaruh pada nilai laporan keuangan tersebut. Keterlambatan penyampaian laporan keuangan dapat dikatakan akan menyebabkan distorsi nilai dan manfaat dari laporan keuangan bersangkutan.

Terkait dengan ketepatwaktuan laporan keuangan tahunan, ukuran perusahaan juga merupakan bagian yang mempengaruhi cepat atau lambat laporan keuangan tersebut disampaikan kepada publik. Besar kecilnya ukuran perusahaan juga dipengaruhi oleh kompleksitas operasional, variabilitas dan intensitas transaksi perusahaan tersebut yang tentunya akan berpengaruh terhadap kecepatan dalam menyajikan laporan keuangan kepada publik (Rachmawati, 2008). Penelitian (Rachmawati, 2008) menunjukkan bahwa ukuran perusahaan berpengaruh positif terhadap timeliness, artinya semakin besar ukuran perusahaan, maka semakin tinggi ketepatwaktuan perusahaan dalam menyampaikan laporan 
keuangannya. (Purnawanti, 2013) yang menemukan bukti empiris bahwa ukuran perusahaan tidak mempengaruhi ketepatwaktuan penyampaian laporan keuangan.

Tingkat profitabilitas suatu perusahaan juga akan akanmempengaruhi ketepatwaktuan manajemen untuk melaporkan kinerja keuangannya. Apabila suatu perusahaan memiliki profitabilitas perusahaan yang rendah maka pihak manajemen akan cenderung tidak tepat waktu dalam menyampaikan laporan keuangan perusahaannya, sedangkan jika perusahaan memiliki profitabilitas yang tinggi maka pihak manajemen akan cenderung lebih tepat waktu dalam menyampaikan laporan keuangan perusahaannya kepada publik.

Keberadaan tata kelola yang baik dalam sebuah perusahaan (Good Corporate Governance) menjadi salah satu faktor yang mempengaruhi ketepatwaktuan penyampaian laporan keuangan. Perusahaan telah menerapkan Good Corporate Governance dengan baik, akan menyebabkan penyampaian laporan keuangan lebih tepat waktu kepada publik. Hal itu karena manajemen telah memiliki tahap tahapan dalam proses laporan keuangannya serta telah memenuhi prinsip-prinsip good corporate governance. Keberadaan teori keagenan yang juga menjelaskan hubungan yang terjadi antar agen dan prinsipal yang memunculkan asimetri informasi yang pada akhirnya berujung dengan konflik (Sulistyo, 2010). Penyampaian pelaporan keuangan yang tepat waktu kepada publik diharapkan dapat mengurangi timbulnya asimetri informasi antara perusahaan dengan pemakai laporan keuangan. Hal tersebut dikarenakan ketepatwaktuan pelaporan keuangan akan mengurangi kecurangan pihak agen 
Gusti Ayu Putu Yasinta Darmawan dan I Made Pande Dwiana Putra. Pengaruh...

sebagai pihak yang memiliki informasi yang lebih banyak dibandingkan dengan pihak prinsipal untuk memanipulasi data.

Berdasarkan penjelasan diatas, mengenai masih adanya ketidakkonsistenan hasil penelitian terdahulu mengenai ukuran perusahaan dan profitabilitas dan adanya variabel lain yakni kualitas good coporate governance yang terindikasi dapat memperkuat maupun memperlemah terhadap ketepatwaktuan penyampaian laporan keuangan, maka mendorong peneliti melakukan penelitian kembali untuk melihat pengaruh faktor ukuran perusahaan dan profitabilitas tersebut terhadap ketepatwaktuan penyampaian laporan keuangan dengan Good Corporate Governance sebagaipememoderasi. Adapun sampel dalam penelitian ini adalah perusahaan-perusahaan yang terdaftar dalam penilaian CGPI pada tahun 20112015. Peneliti memilih perusahaan yang terdaftar dalam penilaian CGPI dikarenakan kebutuhan data indeks CG yang digunakan sebagai proksi dari Good Corporate Governance. Berdasarkan latar belakang yang telah disampaikan, maka peneliti mengusulkan penelitian dengan judul, "Pengaruh Ukuran Perusahaan dan Profitabilitas, pada Ketepatwaktuan Penyampaian Laporan Keuangan dengan Good Corporate Governance sebagai Variabel Pemoderasi.

Berdasarkan uraian diatas makaapokok permasalahan dalam penelitian ini yaitu: 1) Apakah ukuran perusahaan memiliki pengaruh pada ketepatwaktuan penyampaian laporan keuangan?; 2) Apakah profitabilitas memiliki pengaruh pada ketepatwaktuan penyampaian laporan keuangan?; 3) Apakah good corporate governance memoderasi pengaruh ukuran perusahaan pada ketepatwaktuan penyampaian laporan keuangan?; 4) apakahgood corporate governance 
memoderasi pengaruh profitabilitas pada ketepatwaktuan penyampaian laporan keuangan?. Adapun tujuan yang ingin dicapai dalam penelitian ini yaitu: 1) Untuk menganalisa apakah ukuran perusahaan memiliki pengaruh pada ketepatwaktuan penyampaian laporan keuangan; 2) Untuk menganalisa apakah profitabilitas memiliki pengaruh pada ketepatwaktuan penyampaian laporan keuangan; 3) Untuk menganalisa apakah good corporate governance mampu memoderasi pengaruh ukuran perusahaan pada ketepatwaktuan penyampaian laporan keuangan; 4) untuk menganalisa apakah good corporate mampu memoderasi pengaruh ukuran perusahaan pada ketepatwaktuan penyampaian laporan keuangan.

Teori keagenan (agency theory) adalah teori yang membahas tentang adanya hubungan keagenan atau kontrak antara manajeman perusahaan (agen) dengan pemilik perusahaan (prinsipal). Prinsipal sebagai pemasok modal memberikan kepercayaan pada agen untuk mengelola aset yang telah ditetapkan dan agen memiliki kewajiban melaporkan informasi yang berkaitan dengan perusahaan kepada principal (Astika \& Pratini, 2013).

Menurut Standar Akuntasi Keuangan yang dikeluarkan oleh Ikatan Akuntan Indonesia tujuan laporan keuangan adalah untuk menyediakan informasi yang menyangkut posisi keuangan, kinerja, serta perubahan posisi keuangan suatu perusahaan yang bermanfaat bagi sejumlah besar pemakai dalam pengambilan keputusan. Laporan keuangan yang disusun untuk tujuan ini memenuhi kebutuhan bersama sebagian besar pemakai.Laporan keuangan juga menunjukkan apa yang 
Gusti Ayu Putu Yasinta Darmawan dan I Made Pande Dwiana Putra. Pengaruh...

telah dilakukan manajemen, atau pertangggungjawaban manajemen atas sumber daya yang dipercayaan kepadanya.

Corporate Governance adalah konsep untuk peningkatan kinerja perusahaan melalui supervisi atau monitoring kinerja manajemen dan menjamin akuntabilitas manajemen terhadap stakeholder dengan mendasarkan pada kerangka peraturan (M. Nasution dan D. Setiawan, 2007).Corporate Governancedapat didefinisikan sebagai susunan aturan yang menentukan hubungan antara pemegang saham, manajer, kreditor, pemerintah, karyawan, dan stakeholder internal dan eksternal yang lain sesuai dengan hak dan tanggungjawabnya. Good corporate governance juga diperlukan untuk mendorong terciptanya pasar yang efisien, transparan dan konsisten dengan peraturan perundang-undangan.

Menurut Husnan (1992), rasio profitabilitas digunakan mengukur keefektivan manajemen secara keseluruhan sebagaimana ditunjukkan dari keuntungan yang diperoleh dari penjualan dan investasi. Perusahaan yang memiliki profitabilitas akan menghasilkan laporan keuangan perusahaan yang mengandung berita baik. Perusahaanyang memiliki laporan keuangan dengan berita baik akan cenderung menyerahkan laporan keuangannya tepat waktu kepada publik. Hal ini juga berlaku jika profitabilitas perusahaan rendah dimana hal ini mengandung berita buruk, sehingga perusahaan cenderung tidak tepat waktu menyerahkan laporan keuangannya (Hilmi dan Ali, 2008).

Menurut (Saleh, 2004) bahwa ukuran perusahaan dapat menunjukkan seberapa besar informasi yang terdapat di dalamnya, sekaligus mencerminkan kesadaran dari pihak manajemen mengenai pentingnya informasi, baik bagi pihak 
ISSN: 2302-8556

E-Jurnal Akuntansi Universitas Udayana Vol.25.1.Oktober (2018): 497-552

eksternal perusahaan maupun pihak internal perusahaan. Perusahaan besar cenderung untuk menyajikan laporan keuangan lebih tepat waktu daripada perusahaan kecil.

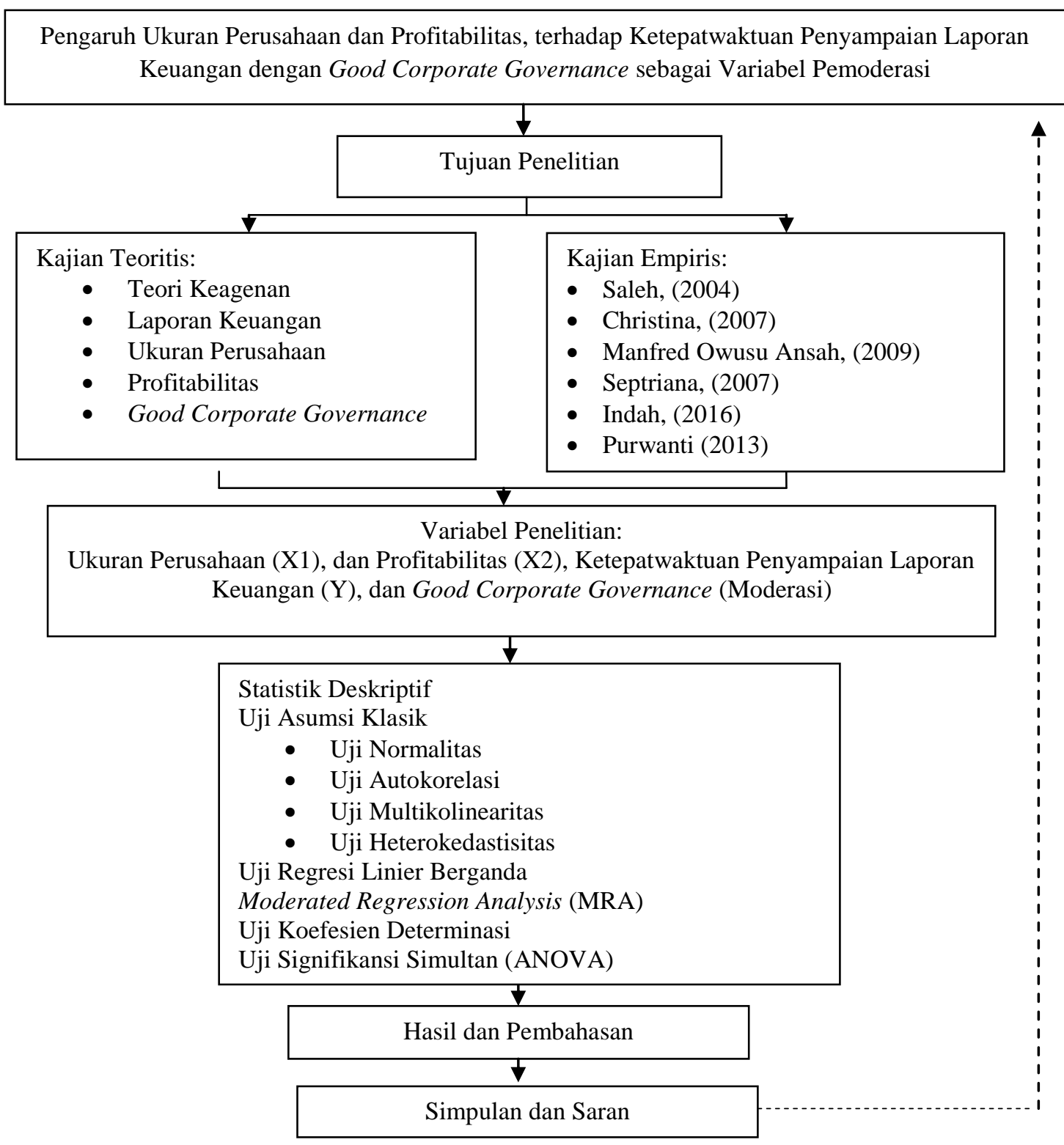

\section{Gambar 1. Kerangka Konseptual Penelitian}

Kerangka konseptual adalah hubungan logis antara kajian empirisnya serta landasan teorinya. Kerangka konseptual menunjukkan pengaruh antar variabel 
Gusti Ayu Putu Yasinta Darmawan dan I Made Pande Dwiana Putra. Pengaruh...

dalam penelitian. Gambar 1 mendeskripsikan pengaruh variabel independen yaitu ukuran perusahaan $\left(\mathrm{X}_{1}\right)$, dan profitabilitas $\left(\mathrm{X}_{2}\right)$, pada ketepatwaktuan penyampaian laporan keuangan (Y) sebagai variabel dependen dengan Good Corporate Governance $\left(\mathrm{X}_{4}\right)$ sebagai variabel moderasi.

Terkait dengan ketepatwaktuan laporan keuangan tahunan, ukuran perusahaan juga menentukan kecepatan pelaporan keuangan. Besar kecilnya ukuran perusahaan juga mempengaruhi kompleksitas operasional, variabilitas dan intensitas transaksi perusahaan tersebut yang tentunya akan berpengaruh terhadap kecepatan dalam menyajikan laporan keuangan kepada publik. Hasil penelitian yang dilakukan oleh (Septriana, 2007) bahwa ukuran perusahaan berpengaruh negatif terhadap ketepatanwaktu penyampaian laporan keuangan karena perusahaan besar akan cenderung lebih tepat waktu dibanding perusahaan kecil. Hilmi dan Ali (2008) menyatakan bahwa perusahaan yang memiliki sumber daya (aset) yang besar memiliki lebih banyak sumber informasi keuangan maka akan memungkinkan perusahaan untuk menyampaikan laporan keuangannya dengan tepat waktu. Hasil penelitian yang dilakukan oleh (Amalia dan Setiady, 2006) menunjukkan bahwa ukuran perusahaan berpengaruh positif terhadap ketepatan waktu pelaporan keuangan.

$\mathrm{H}_{1}$ : Ukuran perusahaan berpengaruh positif pada ketepatwaktuan penyampaian laporan keuangan.

Perusahaan yang memiliki tingkat profitabilitas yang lebih tinggi membutuhkan waktu dalam pengauditan laporan keuangan lebih cepat dikarenakan keharusan untuk menyampaikan kabar baik secepatnya kepada publik.Apabilaperusahaan memiliki profitabilitas yang tinggi, hal tersebut 
merupakan berita baik (good news) bagi stakeholder, sehingga perusahaan cenderung ingin lebih cepat mengungkapkan berita baik tersebut agar mendapatkan respon positif dari stakeholder. Mengingat profitabilitas merupakan salah satu cara bagi stakeholders untuk menilai kinerja perusahaan sehingga ketika perusahaan memiliki profitabilitas tinggi perusahaan akan segera mengungkapkan laporan keuangan tersebut untuk memberikan kabar baik bagi investor dengan harapan investor akan memberikan respon positif atas berita baik tersebut.

$\mathrm{H}_{2}$ : Profitabilitas berpengaruh positif pada ketepatwaktuan penyampaian laporan keuangan.

Perusahaan besar cenderung untuk menyajikan laporan keuangan lebih tepat waktu daripada perusahaan kecil. Semakin besar ukuran perusahaan, maka semakin banyak informasi yang terkandung di dalam perusahaan, dan semakin besar pula tekanan untuk mengolah informasi tersebut, sehingga pihak manajemen perusahaan akan memiliki kesadaran yang lebih tinggi mengenai pentingnya infomasi, dalam mempertahankan eksistensi perusahaan. Semakin tinggi kesadaran manajemen mengenai pentingnya informasi bagi pihak - pihak yang berkepentingan, akan membuat penyajian dan penyampaian laporan keuangan menjadi lebih tepat waktu. Berdasarkan analisis dan temuan penelitian terdahulu, maka hipotesis penelitian dinyatakan sebagai berikut.

$\mathrm{H}_{3}$ : Good Corporate Governance memperkuat pengaruh ukuran perusahaan pada ketepatwaktuan penyampaian laporan keuangan.

Profitabilitas perusahaan merupakan kemampuan perusahaan dalam menghasilkan laba bersih dari aktivitas yang dilakukan pada periode akuntansi 
Gusti Ayu Putu Yasinta Darmawan dan I Made Pande Dwiana Putra. Pengaruh...

dengan menggunakan presentase dalam pengukurannya. Profitabilitas dapat menjadi pertimbangan penting bagi investor dalam keputusan investasinya, karena semakin besar dividen (dividend payout) akan semakin menghemat biaya modal, di sisi lain para manajer (insider) menjadi meningkat powernya bahkan bisa meningkatkan kepemilikannya akibat penerimaan deviden sebagai hasil keuntungan yang tinggi. Dengan tawaran mendapatkan hasil keuntungan yang tinggi, diharapkan dapat menarik minat investor didalam berinvestasi. Dengan demikian jika suatu perusahaan memiliki profitabilitas yang tinggi manajemen cenderung akan menyelesaiakan laporan keuanganya dengan cepat agar pihak yang berkepentingan dengan perusahaan bisa cepat mengetahui laba yang dihasilkan perusahaan tersebut.

Dengan penerapan good corporate governance maka proses pengambilan keputusan akan berlangsung secara lebih baik sehingga akan menghasilkan keputusan yang optimal, dan dapat mempercepat penyampaiaan laporan keuangan.Jika sebuah perusahaan melaksanakan dengan baik, dan memiliki profitabilitas yang besar maka penyampaian laporan keuangan laporan keuangan akansemakin cepat karena kreteria laporan keuangan yang baik sudah terpenuhi.

$\mathrm{H}_{4}$ : Good Corporate Governance memperkuat pengaruh profitabilitas pada ketepatwaktuan penyampaian laporan keuangan.

\section{METODE PENELITIAN}

Desain penelitian yang digunakan dalam penelitian ini adalah pendekatan kuantitatif yang berbentuk asosiatif. Sugiyono, (2014) menyatakan bahwa penelitian asosiatif adalah penelitian yang bertujuan untuk mengetahui hubungan 
dua variabel atau lebih. Desain penelitian dalam penelitian ini dapat dilihat pada Gambar 2.

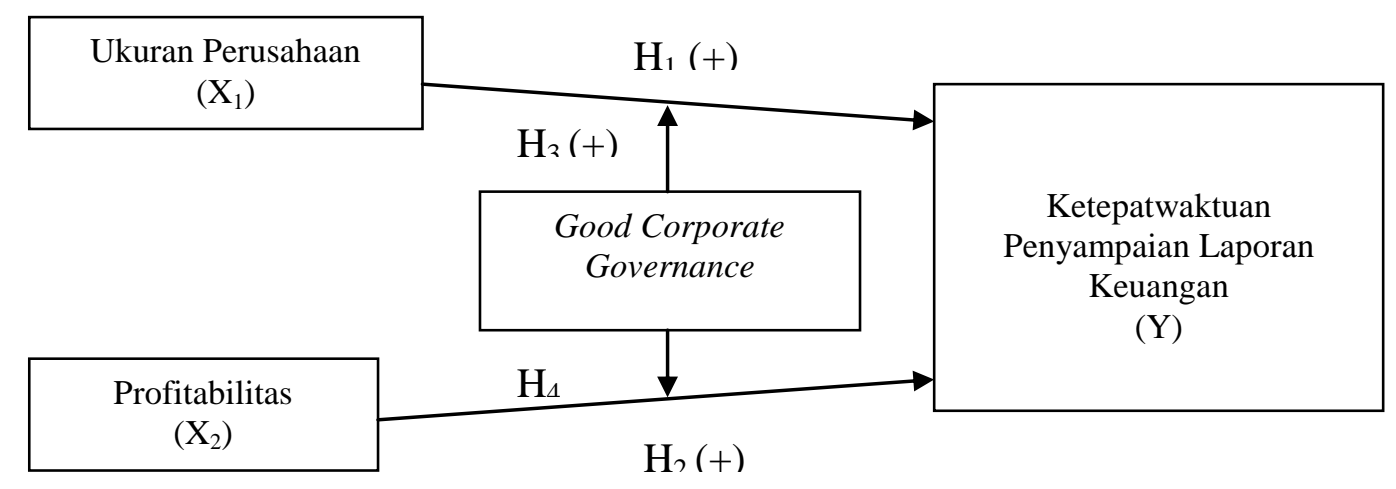

Gambar 2. Desain Penelitian

Lokasi penelitian merupakan suatu tempat atau wilayah dimana penelitian tersebut akan dilakukan. Adapun lokasi penelitian ini dilakukan pada perusahaan yang terdaftar dalam penilaian CGPI tahun 2011-2015.

Objek penelitian yang digunakan adalah data sekunder dengan sumber dari laporan keuangan auditan yang terdaftar di BEI dan data dianalisa adalah tahun 2011 sampai 2015. Variabel dependen yang digunakan adalah ukuran perusahaan dan profitabilitas. Sedangkan variabel independen yang digunakan yaitu ketepatwaktuan penyampaian laporan keuangan. Variabel pemoderasi yang digunakan adalah good corporate governance. Selanjutnya dalam penelitian ini populasi yang digunakan adalah perusahaan yang terdaftar dalam penilaian CGPI tahun 2011-2015.

Variabel dependen dalam penelitian ini adalah ketepatwaktuan penyampaian laporan keuanganVariabel independennya adalah pengetahuan, 
Gusti Ayu Putu Yasinta Darmawan dan I Made Pande Dwiana Putra. Pengaruh...

ukuran perusahaan dan profitabilitas. Sedangkan Variabel moderasi dalam penelitian ini adalah good corporate governance.

Ketepatwaktuan penyampaian laporan keuangan akan mempengaruhi pengguna laporan keuangan ketika mengambil keputusan karena semakin cepat waktu publikasinya, maka semakin cepat keputusan dapat diambil.Variabel dependen ini diukur berdasarkan tanggal penyampaian laporan keuangan tahunan auditan ke Bapepam. Perusahaan dikategorikan tidak tepat waktu dalam penyampaian laporan keuangan apabila melaporkannya setelah tanggal 30 April, dan perusahaan yang tepat waktu adalah perusahaan yang menyampaikan laporan keuangan mulai dari berakhirnya tahun buku sampai dengan tanggal 30 April.

$\mathrm{KW}=$ akhir tahun buku - tanggal publikasi ke BEI.

Ukuran perusahaan adalah besar kecilnya perusahaan yang diukur dengan menggunakan total aset total asset yang dimiliki perusahaan atau total aktiva perusahaan klien yangtercantum pada laporan keuangan perusahaan akhir periode yang telah diaudit menggunakan proksi logaritma natural total asset (Angruningrum dan Wirakusuma, 2013)

Ukuran Perusahaan $=$ Ln $($ total asset $)$

Perusahaan yang memiliki tingkat profitabilitas yang lebih tinggimembutuhkan waktu dalam pengauditan laporan keuangan lebih cepat dikarenakan keharusan untuk menyampaikan kabar baik secepatnya kepada publik.Profitabilitas dalam penelitian ini diproksikan dengan Return on Assets(ROA). ROA digunakan untukmengukur kemampuan perusahaan dalam memanfaatkan aktivanya untuk 
memperoleh laba.Profitabilatas menurut Suad Hasan, (1992) dapat dirumuskan dengan:

$$
\mathrm{ROA}=\frac{\text { laba bersi } h \text { setela } h \text { pajak }}{\text { total aktiva }} \times 100 \%
$$

Good Corporate Governance dalam penelitian ini diukur menggunakan score CGPI perusahaan dalam penilaian The Indonesian Most Trusted Companies Corporate Gonvernance Perception Index (CGPI) yang dipublikasikan oleh majalah SWA. Alasan digunakan Corporate Gonvernance Perception Index dikarenakan laporan yang dilakukan oleh IICG dapat memberikan gambaran secara langsung mengenai penerapan GCG di dalam perusahaan.

Populasi adalah wilayah generalisasi yang terdiri atas obyek yangmempunyai kualitas dan karakteristik tertentu yang ditetapkan oleh peneliti untuk dipelajari. Populasi yang digunakan dalam penelitian ini adalah seluruh perusahaan yang tercatat di BEI.

Sampel adalah bagian dari jumlah karakteristik yang dimiliki oleh populasi tersebut (Sugiyono, 2013). Metode penentuan sampel menggunakan teknik probability sampling, yaitu pengambilan sampel berdasarkan kriteria sebagai berikut: 1) Perusahaan yang terdaftar di BEI dan dan masuk dalam peringkat CGPI yang diberikan oleh IICG tahun 2011-2015. 2) Perusahaan yang telah menerbitkan laporan keuangan tahunan yang telah diaudit selama tahun 20112015. 3) Perusahaan yang menerbitkan laporan keuangan dalam mata uang rupiah. 4) Perusahaan yang memiliki kelengkapandata tentang laporan keuangan yang berkaitan dengan pengukuran variabel - variabel yang digunakan dalam penelitian ini. 
Gusti Ayu Putu Yasinta Darmawan dan I Made Pande Dwiana Putra. Pengaruh...

Metode pengumpulan data yang digunakan adalah metode observasi non partisipan yaitu peneliti dapat melakukan observasi sebagai pengumpulan data tanpa ikut terlibat dari fenomena yang diamati. Metode ini dapat memperoleh data dengan melakukan pengumpulan data melalui pengamatan dan pencatatan serta mempelajari uraian-uraian dari buku-buku, jurnal, skripsi, tesis, dan melakukan akses BEI melalui www.idx.co.id.

Jenis data dalam penelitian ini adalah data kuantitatif dan kualitatif. Kuantitatif meliputi laporan keuangan tahunan perusahaan yang terdaftar dalam penilaian CGPI yang terdaftar di Bursa Efek Indonesia. Data kualitatif meliputi perusahaan yang terdaftar dalam penilaian CGPI di Bursa Efek Indonesia tahun 2011-2015 dan profil perusahan yang terdaftar dalam penilaian CGPI yang terdaftar di Bursa Efek Indonesia tahun 2011-2015.

Teknik analisis data adalah teknik pengolahan terhadap data yang telah dikumpulkan yang dapat menghasilkan suatu informasi yang digunakan untuk menjawab masalah-masalah yang telah dirumuskan dalam suatu penelitian. Teknik analisis data yang digunakan untuk menyelesaikan masalah-masalah dalam penelitian ini adalah analisis Moderated Regression Analysis (MRA) dengan menggunakan program Statistical Product and Service Solution (SPSS 20). Teknik ini digunakan untuk melihat kemampuan pengaruh umur perusahan dan profitabilitasterhadap ketepatwaktuan penyampaian laporan keuangan dengan Good Corporate Governancesebagai pemoderasi. Tahap analisis yang digunakan dalam penelitian ini yaitu, ujistatistik deskriptif, uji asumsi klasik, uji analisis regresi,dan pengujian hipotesis.Statistik Deskriptif adalah statistik yang berfungsi 
untuk mendeskripsikan atau memberi gambaran terhadap obyek yang diteliti melalui data sampel atau populasi sebagaimana adanya, tanpa melakukan analisis dan membuat kesimpulan yang berlaku untuk umum. Uji Asumsi Klasik adalah persyaratan statistik yang harus dipenuhi pada analisis (www.konsultanstatistik.com). Pengujian asumsi klasik dilakukan untuk memastikan dan meyakinkan bahwa model yang dibuat telah valid dan telah memenuhi asumsi-asumsi dasar dalam analisis regresi. Analisis regresi yang dilakukan untuk mengetahui seberapa besar pengaruh antar variabel independen terhadap variabel dependen.Analisis regresi linier berganda digunakan untuk mengetahui bagaimana keadaan (naik turunnya) variabel dependen apabila dua atau lebih dan variabel independen sebagai faktor prediktor dimanipulasi (dinaikturunkan nilainya). Bentuk persamaan linier berganda adalah sebagai berikut:

$$
\mathrm{Y}=\alpha+\beta_{1} \mathrm{X}_{1}+\beta_{2} \mathrm{X}_{2}+\varepsilon
$$

\section{Keterangan:}

$\mathrm{Y} \quad=$ Ketepatan Waktu Penyampaian Laporan Keuangan

$\mathrm{X}_{1} \quad=$ Ukuran Perusahaan

$\mathrm{X}_{2} \quad=$ Profitabilitas

$\varepsilon \quad=$ Error

$\alpha=$ Konstanta

$\beta \quad=$ Koefisien Regresi

Regresi dengan melakukan uji interaksi antar variabel disebut dengan Moderated Regresion Analysis (Utama, 2009). MRA merupakan aplikasi khusus regresi berganda linier dimana dalam persamaan regresinya mengandung unsur interaksi (Perkalian dua atau lebih variabel independen). 


$$
Y=\alpha+\beta_{1} X_{1}+\beta_{2} X_{2}+\beta_{3} X_{3}+\beta_{4} X_{1} X_{3}+\beta_{5} X_{2} X_{3}+\varepsilon
$$

\section{Keterangan:}

$\begin{array}{lll}\mathrm{Y} & = & \begin{array}{l}\text { Simbol yang menunjukkan ketepatanwaktu penyampaian } \\ \text { laporan keuangan tahunan }\end{array} \\ \mathrm{X}_{1} & = & \text { Ukuran Perusahaan } \\ \mathrm{X}_{2} & = & \text { Profitabilitas } \\ \mathrm{X}_{3} & = & \text { Good Corporate Governance } \\ \mathrm{X}_{1} \mathrm{X}_{3} & = & \text { Interaksi antara variabel Ukuran Perusahaan dengan } \\ & & \text { variabel Good Corporate Governance } \\ \mathrm{X}_{2} \mathrm{X}_{3} & = & \text { Interaksi antara variabel Profitabilitas dengan variabel } \\ \varepsilon & = & \text { Eood Corporate Governance } \\ \alpha & = & \text { Konstanta } \\ \beta & = & \text { Koefisien regresi }\end{array}$

Pengukuran koefisien determinasi dilakukan untuk mengetahui persentase pengaruh variabel independen terhadap perubahan variabel dependen. Dari ini diketahui seberapa besar variabel dependen mampu dijelaskan oleh variabel independennya.

Uji signifikansi simultan (ANOVA) bertujuan untuk mengetahui apakah dalam penelitian ini model yang digunakan layak untuk digunakan atau tidak. Kriteria pengujian, bila nilai signifikan dalam uji $\mathrm{F} \leq \alpha$ sebesar $5 \%$, maka variabel $\mathrm{X}$ berpengaruh secara simultan terhadap variabel Ydan model penelitian ini layak untuk digunakan.

Uji hipotesis dalam penelitian ini dilakukan untuk mengetahui apakah variabel independen secara parsial memengaruhi variabel dependen. Kriteria uji hipotesis yaitu $\mathrm{H}_{1}$ diterima apabila nilai $p$-value $\beta_{1} \leq$ dari $\alpha, \beta_{1}$ positif maka $\mathrm{H}_{1}$ diterima. $\mathrm{H}_{2}$ diterima apabila nilai $p$-value $\beta_{2} \leq$ dari $\alpha, \beta_{2}$ positif maka $\mathrm{H}_{2}$ diterima. $\mathrm{H}_{3}$ diterima apabila nilai $p$-value $\beta_{4} \leq$ dari $\alpha, \beta_{4}$ positif maka $\mathrm{H}_{3}$ diterima, artinya 
variabel pemoderasi memperkuat pengaruh variabel independen terhadap variabel dependen. $\mathrm{H}_{4}$ diterima apabila nilai $p$-value $\beta_{5} \leq$ dari $\alpha, \beta_{5}$ positif maka $\mathrm{H}_{4}$ diterima, artinya variabel pemoderasi memperkuat pengaruh variabel independen terhadap variabel dependen.

\section{HASIL DAN PEMBAHASAN}

Nilai minimum variabel ukuran perusahaan adalah 4,49 yaitu PT Bank Tabungan Negara (Persero) Tbk pada tahun 2011, dan nilai maksimumnya adalah 6,89 yang terdapat pada PT Timah (Persero) Tbk pada tahun 2014. Rata-rata untuk ukuran perusahaan adalah 5,7864 sedangkan standar deviasi ukuran perusahaan adalah 0,75483 lebih kecil dari mean yang berarti tidak terdapat penyimpangan pada nilai rata-rata ukuran perusahaan.Nilai minimum variabel profitabilitas adalah0,06yaitu PT Aneka Tambang Tbk pada tahun 2015, dan nilai maksimumnya adalah 0,27 yang terdapat pada PT Timah (Persero) Tbk pada tahun 2011. Ratarata untuk profitabilitas adalah0,0563sedangkan standar deviasi untuk profitabilitas adalah 0,06551 lebih kecil dari mean yang berarti tidak terdapat penyimpangan pada nilai rata-rata profitabilitas.Nilai minimum variabel ketepatwaktuanpenyampaian laporan keuanganadalah 23,00 yaitu PT Bank Negara Indonesia Tbk pada tahun 2015, dan nilai maksimumnya adalah 113,00 yang terdapat pada PT Aneka Tambang Tbk pada tahun 2015 dan PT Jasa Marga (Persero) Tbk pada tahun 2011. Rata-rata untuk ketepatwaktuanpenyampaian laporan keuangan adalah 58,4762sedangkan standar standar deviasi untuk ketepatwaktuan penyampaian laporan keuangan19,39731 lebih besar dari mean yang berarti terdapat penyimpangan pada nilai rata ketepatwaktuan.Nilai 
minimum variabel GCG adalah 0,76yaitu PT Timah Tbk pada tahun 2011, dan nilai maksimumnya adalah 0,93 yang terdapat pada PT Bank Mandiri Tbk pada tahun 2015. Rata-rata untuk GCG adalah 0,8602sedangkan standar deviasi untuk GCG adalah 0,03516 lebih kecil dai mean yang berarti tidak terdapat penyimpangan pada GCG.

Data penelitian yang digunakan dikatakan berdistribusi normal apabila apabila nilai Asymp. Sig. (2-tailed) lebih besar dari $\alpha=0,05$. Berdasarkan Tabel 2 di atas, nilai Asymp. Sig. (2-tailed) dari model persamaan yang diuji sebesar 0,8581ebih besar dari 0,05 . Hal ini menunjukkan residual data yang digunakan dalam penelitian ini telah berdistribusi normal.

Berdasarkan hasil uji multikoleniaritas, dapat diketahui nilai tolerance dari variabel ukuran perusahaan, profitabilitas, variabel interaksi antara ukuran perusahaan dengan GCG dan variabel interaksi antara profitabilitas dengan GCG lebih kecil dari 0,01 dan memiliki VIF lebih besar dari 10 yang berarti terdapat gejala multikol didalamnya. Berdasarkan hasil uji run test, diperoleh nilai asymp.sig 0,876 lebih kecil dari $\alpha(0,05)$ sehingga menunjukkan data yang di gunakan dalam penelitian ini bebas dari autokorelasi.

Berdasarkan hasil uji heteroskedastisitas pada Tabel 5 di atas, dapat diketahui nilai signifikansi dari variabel ukuran perusahaan sebesar $0,794(\geq 0,05)$, nilai signifikansi dari variabel profitabilitas sebesar $0,556(\geq 0,05)$, nilai signifikansi dan nilai signifikansi dari variabel GCG sebesar $0,766(\geq 0,05)$. Oleh karena nilai signifikansi dari masing-masing variabel independen memiliki nilai 
lebih dari 0,05 maka dapat disimpulkan bahwa data yang digunakan pada penelitian ini tidak terdapat masalah heteroskedastisitas.

Nilai konstanta 85,381 memiliki arti ketika variabel ukuran perusahaan dan profitabilitasnya konstan atau nol maka selisih hari akan meningkat sebesar 85,381 hari. jika ukuran perusahaan meningkat 1 persen maka selisih hari akan menurun sebesar 5,762 hari. Jika profitabilitas meningkat 1 persen maka ketepatwaktuan akan meningkat sebesar 114,401 hari.

\section{Tabel 1.}

Hasil Moderated Regression Analysis

\begin{tabular}{lccc}
\hline Model & \multicolumn{2}{c}{ Unstandardized Coefficients } & Sig. \\
\cline { 2 - 4 } & B & \\
\hline (Constant) & $-116,401$ & $-0,134$ & 0,894 \\
Ukuran Perusahaan & 2,293 & 0,017 & 0,987 \\
Profitabilitas & 2263,440 & 2,663 & 0,012 \\
GCG & 256,610 & 0,252 & 0,802 \\
X1.Z & $-12,868$ & $-0,081$ & 0,936 \\
X2.Z & $-2605,007$ & $-2,565$ & 0,015 \\
\hline
\end{tabular}

Sumber: Data diolah, 2018

Nilai koefisien regresi GCG memoderasi ukuran perusahaan sebesar12,868menunjukkan bahwa bila interaksi antara ukuran perusahaandengan $G C G$ naik satu satuan, maka ketepatwaktuan penyampaian laporan keuangan akan mengalami penurunan sebesar 12,868persen dengan asumsi variabel lainnya konstan.Nilai koefisien regresiGCGmemoderasi profitabilitas sebesar -2605,007 menunjukkan bahwa bila interaksi antara profitabilitas dengan GCGnaik satu satuan, maka ketepatwaktuan penyampaian laporan keuangan akan mengalami penurunan sebesar 2605,007satuan dengan asumsi variabel lainnya konstan. 
Tabel 2.

Hasil Uji Koefisien Determinasi

\begin{tabular}{lcccc}
\hline Model & R & R Square & Adjusted R Square & Std. Error of the Estimate \\
\hline 1 & $0,557^{\mathrm{a}}$ & 0,310 & 0,215 & 17,19085 \\
\hline Sumber: Data diolah, 2018 & & &
\end{tabular}

Berdasarkan hasil uji koefisien determinasi diperoleh nilai Adjusted $R$ Square adalah sebesar 0,215 yang berarti variabel ukuran perusahaan, profitabilitas, GCG, variabel interaksi antara ukuran perusahaan dan GCG, serta variable interaksi profitabilitas dan GCG berpengaruh sebesar 21,5 persen pada ketepatwaktuanpenyampaian laporan keuangan dan 73,5 persen ketepawaktuan penyampaian laporan keuangan dipengaruhi oleh variabel lainnya yang tidak masuk dalam penelitian.

Tabel 3.

Hasil Uji Signifikansi Simultan (ANOVA)

\begin{tabular}{lccccc}
\hline Model & Sum of Squares & df & Mean Square & F & Sig. \\
\hline Regression & 4787,561 & 5 & 957,512 & 3,240 & $0,016^{\mathrm{b}}$ \\
Residual & 10638,915 & 36 & 295,525 & & \\
Total & 15426,476 & 41 & & & \\
\hline
\end{tabular}

Sumber: Data diolah, 2018

Berdasarkan hasil uji Signifikansi Simultan (ANOVA) diketahui nilai signifikansi $0,016 \leq \alpha(0,05)$ yang berarti model layak untuk diuji regresi dan variabel ukuran perusahaan dan profitabilitas berpengaruh secara simultan pada ketepatwaktuan penyampaian laporan keuangan.

Uji statistik t dilakukan untuk mengetahui seberapa besar pengaruh variabel independen terhadap variabel dependen secara parsial. Uji statistik t dilakukan dengan membandingkan hasil nilai signifikansi dengan $\alpha=0,05$ dan dapat dijelaskan sebagai berikut. Berdasarkan hasil uji Tabel 2. diketahui bahwa 
hubungan antara ukuran perusahaandengan ketepatwaktuan penyampaian laporan keuangan memiliki nilai $\beta_{1}$ sebesar $-5,762$ dan tingkat signifikansi sebesar 0,137 lebih besar dari $\alpha(0,05)$. Artinya ukuran perusahaan tidak berpengaruh pada ketepatwaktuan penyampaian laporan keuangan. Dengan demikian, $\mathrm{H}_{1}$ yang menyatakan bahwa ukuran perusahaan berpengaruh positif terhadap ketepatwaktuan penyampaian laporan keuangan ditolak.

Berdasarkan hasil uji Tabel 2. diketahui bahwa interaksi antara profitabilitas dengan ketepatwaktuan penyampaian laporan keuangan memiliki nilai $\beta_{2}$ sebesar 114,401 dan tingkat signifikansi sebesar 0,013lebih kecil dari $\alpha(0,05)$. Artinya profitabilitas berpengaruh positif pada selisih hari akhir tahun buku dengan tanggal publikasi laporan keuangan. Dengan demikian, $\mathrm{H}_{2}$ yang menyatakan bahwa profitabilitas berpengaruh positif terhadap ketepatwaktuan penyampaian laporan keuangan ditolak. Berdasarkan hasil uji Tabel 1. diketahui bahwa hubungan antara GCG memoderasi ukuran perusahaan dengan ketepatwaktuan penyampaian laporan keuangan memiliki nilai $\beta_{4}$ sebesar $-12,868$ dan tingkat signifikansi sebesar 0,936 lebih besar dari $\alpha(0,05)$. Artinya GCG tidak mampu memoderasi pengaruh ukuran perusahaan pada ketepatwaktuan penyampaian laporan keuangan. Dengan demikian, $\mathrm{H}_{3}$ yang menyatakan bahwa GCG memperkuatpengaruh ukuran perusahaan terhadap ketepatwaktuan penyampaian laporan keuangan ditolak. Berdasarkan hasil uji Tabel 1. diketahui bahwa hubungan GCG memoderasi pengaruh profitabilitas dengan ketepatwaktuan penyampaian laporan keuangan memiliki nilai $\beta_{5}$ sebesar $-2.605,007$ dan tingkat signifikansi sebesar 0,015 lebih kecil dari $\alpha(0,05)$. Artinya GCG mampu 
Gusti Ayu Putu Yasinta Darmawan dan I Made Pande Dwiana Putra. Pengaruh...

memperkuat pengaruh profitabilitas terhadap selisih hari akhir tahun buku dengan tanggal publikasi laporan keuangan. Dengan demikian, $\mathrm{H}_{4}$ yang menyatakan bahwa GCG memperkuat pengaruh profitabilitas terhadap ketepatwaktuan penyampaian laporan keuangan diterima.

Hipotesis pertama dalam penelitian ini menyatakan bahwa ukuran perusahaan tidak berpengaruh terhadap ketepatwaktuan penyampaian laporan keuangan. Berdasarkan hasil analisis regresi berganda, diperoleh nilai $\beta_{1}$ negatif sebesar5,762. Nilai $\beta_{1}$ negatif artinya terjadi hubungan yang negatif antara ukuran perusahaan terhadapselisih hari akhir tahun buku dengan tanggal publikasi laporan keuangan. Ketepatwaktuan penyampain laporan keuangan. Semakin tinggi ukuran perusahaan tidak mempengaruhi kecepatan atau keterlambatan waktu penyampaian laporan keuangan kepada publik. Dengan demikian hasil ini menolak hipotesis $\mathrm{H}_{1}$ yakni ukuran perusahaan berpengaruh positif pada ketepatwaktuan penyampaian laporan keuangan.

Hipotesis kedua dalam penelitian ini menyatakan bahwa profitabilitas berpengaruh positif terhadap ketepatwaktuan penyampaian laporan keuangan. Berdasarkan hasil analisis regresi berganda, diperoleh nilai $\beta_{2}$ positif sebesar114,401. Nilai koefisien positif artinya terjadi hubungan yang positif antara profitabilitas dengan selisih hari akhir tahun buku dengan tanggal publikasi laporan keuangan dan berpengaruh negatif pada ketepatwaktuan penyampaian laporan keuangan. Semakin tinggi profitabilitas makaakansemakin lama waktu penyampaian laporan keuangan kepada publik. Karena perusahaan yang memiliki laba, mungkin saja manajemen laba sehingga sehingga memerlukan waktu yang 
lebih panjang dari perusahaan dengan laba yang kecil atau rugi. Semakin tinggi profitabilitas perusahaan ingin segera mempublikasikan laporan keuangannya untuk menarik investor. Dengan demikian hasil ini menerima hipotesis $\mathrm{H}_{2}$ yakni profitabilitas berpengaruh negatifpada ketepatwaktuan penyampaian laporan keuangan.

Hipotesis ketiga dalam penelitian ini menyatakan bahwa GCG mampu memoderasi ukuran perusahaan terhadap ketepatwaktuan penyampaian laporan keuangan. Berdasarkan hasil analisis Moderated Regression Analysis (MRA), diperoleh nilai kefisien yang negatif dengan signifikansi sebesar 0,936 karena nilai signifikansi lebih besar dari 0,05 maka variabel GCG tidak mampu memoderasi hubungan antara ukuran perusahaan dengan ketepatwaktuan penyampaian laporan keuangan. Hasil ini menunjukan bahwa besar kecilnya ukuran perusahaan tidak dipengaruhi oleh GCG dalam ketepatwaktuan penyampaian laporan keuangan. karena perusahaan cenderung mengedepankan prinsip-prinsip GCG dalam pelaksanaan kegiatan perusahaan serta dalam penyusunan laporan keuangan untuk mendapatkan hasil penilaian yang baik. Hasil penelitian ini menolak hipotesis ketiga dimana good corporate governance mampu memoderasi ukuran perusahaan pada ketepatwaktuan penyampaian laporan keuangan.

Hipotesis keempat dalam penelitian ini menyatakan bahwa GCG mampu memperkuat hubungan antara profitabilitas pada ketepatwaktuan penyampaian laporan keuangan. Berdasarkan hasil analisis Moderated Regression Analysis (MRA), diperoleh nilai koefisien negatif dengan signifikansi sebesar 0,015 karena 
nilai signifikansi lebih kecil dari 0,05 maka variabel GCG mampu memoderasi dengan memperlemah hubungan antara profitabilitas dengan ketepatwaktuan penyampaian laporan keuangan.

GCG berpengaruh positif memperkuat pada hubungan antara profitabilitas dan ketepatwaktuan karena perusahaan cenderung mengedepankan prinsip-prinsip GCG dalam pelaksanaan kegiatan perusahaan serta dalam penyusunan laporan keuangan untuk mendapatkan hasil penilaian yang baik sehingga perusahaan cenderung mengabaikan profitabilitas mereka dalam artian perusahaan menyajikan laporan keuangan apa adanya tanpa melakukan manajemen laba atau manipulasi pada profitabilitas mereka walaupun profitabilitas perusahaan dalam kondisi rendah sekalipun. Hal ini disebabkan sesuai dengan prinsip GCG perusahaan harus memiliki setidaknya komitmen, transparansi, akuntabilitas, responsibilitas, dan independensi dalam menyampaikan laporan keuangan. Sehingga untuk memenuhi aspek prinsip GCG tersebut perusahaan kurang berfokus pada profitabilitas perusahaan namun berfokus pada hasil laporan keuangan yang baik sehingga GCG dapat berpengaruh pada berkurangnya profitabilitas perusahaan.

Hasil dari penelitian ini dapat memberikan wawasan dalam mendeteksi adanya keterlambatan waktu penyampaian laporan keuangan dalam perusahaan yang terdaftar dalam penilaian CGPI. Penelitian ini juga membuktikan tidak semua variabel yang secara teori memengaruhi ketepatwaktuan penyampaian laporan keuangan ketika dilakukan penelitian berpengaruh secara nyata, hal ini 
dimungkinkan terjadi karena adanya perbedaan objek penelitian, periode penelitian, dan kondisi yang berbeda.

Penelitian ini diharapkan akan memberikan kontribusi positif bagi semua pihak khususnya pihak investor dan perusahaan. Bagi pihak perusahaan hendaknya bersungguh-sungguh dalam penerapan dari Good Corporate Governance (GCG). Perusahaan juga diharapkan mengikuti pemeringkatan yang dilakukan oleh IICG karena pada saat ini perusahaan yang ikut dalam pemeringkatan CGPI setiap tahunnya tidak sama dan hanya sebagian kecil dari keseluruhan perusahaan serta hanya beberapa perusahaan yang ikut berturut-turut setiap tahunnya.

\section{SIMPULAN}

Berdasarkan pembahasan hasil penelitian yang telah diuraikan maka dapat disimpulkan yaituukuran perusahaan tidak memiliki pengaruh pada ketepatwaktuan penyampaian laporan keuangan. Perusahaan besar cenderung untuk menyajikan laporan keuangan lebih tepat waktu daripada perusahaan kecil. Hal ini karena perusahaan besar lebih konsisten untuk tepat waktu dibandingkan perusahaan kecil dalam menginfomasikan laporan keuangannya, karena perusahaan besar banyak disorot oleh masyarakat dan stakeholder.

Profitabilitas berpengaruh positif signifikan pada selisih hari akhir tahun buku dengan tanggal publikasi laporan keuangan dan berpengaruh negatif pada ketepatwaktuan penyampaian laporan keuangan.Profitabilitas dalam penelitian ini mendukung teori yang menyatakan bahwa perusahaan yang memiliki profitabilitas tinggi tidak dapat dikatakan bahwa perusahaan tersebut mengandung 
Gusti Ayu Putu Yasinta Darmawan dan I Made Pande Dwiana Putra. Pengaruh...

berita yang baik dan perusahaan yang mengandung berita baik akan cenderung menyerahkan laporan keuangannya secara tepatwaktu.Good Corporate Governance tidak mampu memoderasi pengaruh ukuran perusahaan terhadap ketepatawaktuan penyampaian laporan keuangan.Hal ini dikerenakan semakin besar ukuran perusahaan maka GCG tidak mempengaruhi agar perusahaan tepatwaktu dalam menyampaikan laporannya ke publik. Karena perusahaan cenderung mengedepankan prinsip-prinsip GCG dalam pelaksanaan kegiatan perusahaan serta dalam penyusunan laporan keuangan untuk mendapatkan hasil penilaian yang baik.Good Corporate Governance berpengaruh negatif signifikan pada hubungan antara profitabilitas dengan ketepatwaktuan penyampaian laporan keuangan yang berate GCG mampu memoderasi dengan memperlemah pengaruh profitabilitas terhadap ketepatwaktuan penyampaian laporan keuangan.Tingginya penerapan GCG yang dibarengin dengan profitabilitas yang tinggi dapat memperlambat ketepatwaktuan perusahaan dalam menyampaikan laporan keuangan.

Berdasarkan pembahasan hasil penelitian dan simpulan yang telah diuraikan maka saran yang akan diberikan yaitu Penelitian ini hanya menggunakan Corporate Governance Perception Index (CGPI) sebagai metode pengukuran dari variabel GCG. Peneliti selanjutnya diharapkan menggunakan metode pengukuran variabel good corporate governance (GCG) yang berbeda. Hal ini terkait dengan keterbatasan sampel dari penelitian ini yang tidak terlepas dari kebutuhan data nilai Corporate Governance Perception Index (CGPI). Ini dikarenakan hanya ada beberapa perusahaan go publik non keuangan yang 
terdaftar dalam penilaian CGPI berturut-turut. Hal ini mengakibatkan hasil yang diperoleh dalam penelitian ini mungkin tidak dapat digeneralisasi untuk setiap perusahaan yang ada di Indonesia.

\section{REFERENSI}

Amalia, L. S., \& Setiady, L. (2006). Faktor - Faktor Yang Mempengaruhi Penyelesaian Penyajian Laporan Keuangan Pada Perusahaan Yang Terdaftar Di Bej, (November), Seminar Nasional Good Corporate Governance di Univ. Trisakti Jakarta. 1-29.

Angruningrum, S., \& Wirakusuma, M. G. (2013). Pengaruh Profitabilitas, Leverage, Kompleksitas Operasi, Reputasi KAP dan Komite Audit Pada Audit Delay. E-Jurnal Akuntansi Universitas Udayana, ISSN: 2302-8556, 5(2), 251-270.

Astika, I. B. P., \& Pratini, I. G. A. P. (2013). Fenomena Pergantian Auditor di Bursa Efek Indonesia. E-Jurnal Akuntansi Universitas Udayana 5.2, 2, 470482.

Chen, Ken Y. Elder, Randal J. Hsieh, Yung-Ming. 2005. Corporate Governance and Earnings Management: The Implications of Corporate Governance Best-Practice Principles for Taiwanese Listed Companies. Journal on Business.

Husnan, Suad. 1992. Dasar-dasar Manajemen Keuangan. Edisi Ketiga. Cetakan Pertama. UPP AMP YKPN, Yogyakarta.

Indah. (2016). Pengaruh Umur Perusahaan , Audit Tenure dan Good Corporate Governance pada Kecepatan Publikasi Laporan Keuangan.Jurnal Akuntansi Dan Bisnis, 6(2), 163-172.

Nasution dan Setiawan, 2007. Pengaruh Corporate Governance Terhadap Manajemen Laba Di Industri Perbankan Indonesia. Jurnal Simposium Nasional Akuntansi X.

Purnawanti, Y. (2013). Pengaruh Ukuran Perusahaan, Umur Perusahaan, Profitabilitas, Dan Leverage Terhadap Ketepatan Waktu Pelaporan Keuangan Pada Perusahaan Food And Baverage Yang Terdaftar Di Bursa Efek Indonesia Tahun 2009 - 2013.Jurnal Ekonomi Universitas Pandanaran.

Rachmawati, S. (2008). Pengaruh Faktor Internal dan Eksternal Perusahaan Terhadap Audit Delay dan Timeliness. Jurnal Akuntansi Dan Keuangan, 
10(1), 1-10. https://doi.org/10.9744/jak.10.1.pp\%201-10.

Saleh, R. (2004). Studi Empiris Ketepatan Waktu Pelaporan Keuangan Perusanaan Manufaktur di Bursa Efek Jakarta.Jurnal Akuntansi Universitas Diponogoro.

Septriana, I. (2007). Analisis Faktor-Faktor Yang Berpengaruh Terhadap Ketepatan Waktu Pelaporan Keuangan Perusahaan Bumn Di Indonesia.Jurnal Akuntansi Universitas Dian Nuswantoro Semarang.

Sudarmadji, Ardi dan Sularso, Lana. 2007. Pengaruh Ukuran Perusahaan, Profitabilitas, Laverage, dan Tipe Kepemilikan Perusahaan Terhadap Luas Valutary Disclosure Laporan Keuangan Tahunan,ISSN: 1858-2559

Sulistyo, Wahyu Adhy Noor. 2010. Analisis Faktor-Faktor yang BerpengaruhTerhadap Ketepatan Waktu Penyampaian Laporan Keuangan pada perusahaan yang listing di BEI periode 2006-2008.Skripsi. Program Sarjana FE Undip, Semarang. 